\title{
Mothers' perspective on violence against children: constructing meanings
}

\author{
Olhares maternos acerca da violência contra a criança: constituindo significados
}

Las miradas maternas sobre la violencia contra los niños: la constitución de significados

\section{Ana Cláudia de Souza Monteiro', Ana Tereza Rangel Silva Fernandes', Andréa Baia Machado de Oliveira', Ivonete Vieira Pereira Peixoto', Mônica Custódia do Couto Abreu Pamplona' \\ ' Pará University Center, Undergraduate Program in Nursing. Belém, Pará, Brazil.}

\begin{abstract}
How to cite this article:
Monteiro ACS, Fernandes ATRS, Oliveira ABM, Peixoto IVP, Pamplona MCCA. Mothers' perspective on violence against children: constructing meanings. Rev Bras Enferm [Internet]. 2018;71(1):34-9.

DOI: http://dx.doi.org/10.1590/0034-7167-2016-0568
\end{abstract}

Submission: 11-22-2016 Approval: 03-03-2017

\begin{abstract}
Objective: To explore the construct elaborated by the mother on the meaning of violence against the child and to identify, according to the mother's perspective, which measures are most used for the prevention of this phenomenon. Method: This is a qualitative research, with the participation of thirty mothers, in a health service in the city of Ananindeua, in the state of Pará, Brazil. The methodology consisted of the categorical content analysis, which identified three categories: Violence, Threats of violence and Protective measures. Results: The research showed that mothers attribute different meanings to violence, but the physical and sexual violence were markedly the most highlighted, and the dialogue was the most used protective measure. Conclusion: It is essential to strengthen public policies through effective interventions, seeking solutions to address this phenomenon in all segments of society. Descriptors: Nursing; Domestic Violence; Child Health; Public health; Child Care.
\end{abstract}

\section{RESUMO}

Objetivo: Conhecer qual a construção elaborada pela mãe sobre o significado da violência contra a criança e identificar na visão materna quais as medidas mais utilizadas para a prevenção desse fenômeno. Método: Trata-se de pesquisa qualitativa, com a participação de trinta mães, em um serviço de saúde no Município de Ananindeua, no estado do Pará. O método utilizado do estudo foi a análise de conteúdo categorial, que apontou três categorias: Significados da violência, Ameaças da violência e Medidas protetivas. Resultados: A pesquisa revelou que as mães atribuem significados diversos à violência, porém, marcadamente as violências física e sexual foram as mais destacadas, sendo o diálogo a medida de proteção mais expressiva. Conclusão: É imprescindível o fortalecimento de políticas públicas através de intervenções efetivas, buscando soluções para o enfrentamento desse fenômeno, em todos os seguimentos da sociedade.

Descritores: Enfermagem; Violência Doméstica; Saúde da Criança; Saúde Pública; Cuidados da Criança.

\section{RESUMEN}

Objetivo: Conocer la construcción elaborada por las madres acerca del significado de la violencia contra los niños e identificar en esta perspectiva las medidas de prevención que pueden ser utilizadas para solucionar este problema. Método: Se trata de investigación cualitativa, con la participación de treinta madres, en un servicio de salud en la ciudad de Ananindeua, estado de Pará, Brasil. El método empleado fue el análisis de contenido categorial, del cual surgieron las siguientes categorías: Significados de la violencia; Amenazas de violencia y Medidas de prevención. Resultados: El estudio desvela que las madres atribuyen significados diferentes a la violencia, sin embargo, las violencias física y sexual fueron las más citadas, y el diálogo fue la medida de prevención considerada más eficiente. Conclusión: Se concluye que son imprescindibles políticas públicas más eficientes mediante medidas que enfrenten el problema en la sociedad por completa.

Descriptores: Enfermería; Violencia Doméstica; Salud del Niño; Salud Pública; Cuidados con los Niños. 


\section{INTRODUCTION}

Violence has been one of the most complex contemporary phenomena, invading lives in a variety of ways. Their manifestations are considered negative for society, reaching mainly children and adolescents. In addition to the social outrage it causes, it has serious consequences for the health and development of defenseless beings ${ }^{(1)}$.

This phenomenon is a serious problem of global public health, presenting various causes and several factors that compromise all sociocultural and economic levels of society. Its repercussions experienced in childhood are devastating marks for human development.

According to the World Health Organization (WHO), violence constitutes

The intentional use of physical force or power, threatened or actual, against oneself, another person, or against a group or community, that either results in or has a high likelihood of resulting in injury, death, psychological harm, maldevelopment or deprivation ${ }^{(2)}$.

Therefore, international organizations such as the World Health Organization (WHO) and the United Nations Educational, Scientific and Cultural Organization (UNESCO), which are concerned about the global scene of violence, devise proposals that consist of actions that stimulate the practice of a culture of peace. These organizations seek to establish such a culture within the family and disseminated in schools, which constitutes basic measures for the prevention of violence.

Following the discussions of these institutions, Brazil has also been growing in efforts in recent years in a series of legislation and regulations in the area aimed at violence prevention and health promotion, which comply with international recommendations and advance more substantially than the health sector had initially proposed ${ }^{(3)}$. In spite of all efforts, it is necessary to expand and integrate this initiative among the various public agencies that interface with the phenomenon of violence, as well as the family and civil society, thereby building permanent strategies that break their vicious cycle.

Collaborators emphasize that violence is no longer exclusive to the legal sector, especially since it has become one of the most serious public health problems in Brazil and worldwide. This statement entails not only the contemplation of violence in its consequences for the individual and for society, but also the implementation of preventive measures, by recognizing its determinants or risk factors ${ }^{(4)}$.

Among the types of child violence, physical, sexual, psychological and neglect, among others, are the most common. It usually occurs in the family life of the victim, which characterizes domestic and intra-family violence. Thus, while the former is established among people who do not maintain ties of consanguinity or affection, intra-family violence is generated among persons with consanguineous or domestic ties ${ }^{(4)}$.

Domestic violence against children, in addition to being a painful reality, in revealing the mistreatment perpetrated in the intra-family sphere, also brings short-, medium- and long-term damages, both physical and psychosocial, which can be devastating, since the experiences in childhood reflect in the adult life ${ }^{(5)}$.

Therefore, it is urgent and necessary to intervene in this phenomenon as means to prevent it through short- and longterm goals such as the implementation of public policies, programs and actions that aim at structural, socio-cultural, economic and subjective changes capable of changing the conditions that favor this phenomenon ${ }^{(6)}$.

In this sense, there is a need to understand the phenomenon of the various types of violence and confront it. However, this requires an inter-sectoral and multidisciplinary approach, through specific strategies of promotion and prevention in each sector of society, in an articulated and coordinated way in order to promote transformations to protect children and adolescents against violence ${ }^{(6)}$.

The purpose of this research was to explore the construct elaborated by the mother on the meaning of violence against children and to identify, in the maternal perspective, which measures are most used to prevent this phenomenon, in such a way that they may be subjects of possible interventions by different sectors of society, creating strategies of promotion that help them protect children and adolescents exposed to various hazards to the greatest possible extent.

\section{METHOD}

\section{Ethical aspects}

This article was developed in accordance with the ethical precepts of Resolution 466/12 of the Brazilian National Health Council $^{(7)}$, which consider basic ethical principles that should guide studies involving human beings. The project was submitted to the Research Ethics Committee of the Pará University Center (CESUPA). Participants signed the Informed Consent Form (TCLE), in which confidentiality and anonymity were assured through the use of alphanumeric code thus identified: M (MOTHER), followed by the number corresponding to the order of the participants.

\section{Type of study}

The research is characterized as a field study, with a qualitative and descriptive approach.

\section{Methodological procedures}

\section{Study scenario}

The study was conducted at the Municipal Unit of Jaderlândia, in the municipality of Ananindeua, Metropolitan Region of Belém-PA, Brazil. The municipality has approximately 471,980 inhabitants ${ }^{(8)}$. The Municipal Health Center of Jaderlândia is a service belonging to the health network of the Brazilian Unified Health System (SUS) of Ananindeua municipality, which develops several programs aimed at various social groups, such as Women's Healthcare Programs, Older Adults' Health, Hiperdia Program, tuberculosis, leprosy. Among them, there is the Programa de Assistência Integral a Saúde a Criança (Comprehensive Health and Child Care Program), which attends children aged 0 to 5 years in several care lines that the center manages. 


\section{Data source}

Thirty mothers who had children with ages ranging from 5 to 12 years and were also participating in any service at the Municipal Health Center of Jaderlândia (UMSJ) participated in the study. Mothers with children outside the age range of the research or caregivers who were not mothers or legal guardians of the child were excluded from the survey.

\section{Data collection}

The research was conducted from January to March of 2015 through a semi-structured interview in a reserved room, recorded through audio after due permission. The interview lasted approximately 20 to 30 minutes, in which the mother verbalized her perspective on violence against children and what measures were used by her to prevent the various types of violence in the everyday care of the child.

\section{Data analysis}

The technique used in the study was the Content Analysis in the categorical modality proposed by Bardin ${ }^{(9)}$, which allowed the identification of three categories: "meanings of violence," with sexual and physical violence as a subcategory; "threats of violence," with the subcategory the street space, family; and "protective measures," the subcategory being the dialogue.

\section{RESULTS}

Regarding the socioeconomic-demographic profile, the majority of the interviewed mothers live in a stable union $(47 \%)$, with an income lower than a minimum wage $(43 \%)$; only $13 \%$ earned more than a minimum wage. This fact may be related to a low socioeconomic level and precarious living conditions of this group.

Regarding the schooling of the participants, the majority held a high school degree (53\%), and $17 \%$ account for some elementary school. Regarding the children's age, the minimum age range was between 5 and 12 years, with the mean number of children per informant of one to three children, half of the mothers had two children between the ages of 1 and 10 years.

The analysis of the interviews allowed the identification of three categories: meanings of violence, threats of violence and protective measures, followed by their subcategories.

\section{Meanings of violence}

When the participants were approached about the meanings attributed in relation to violence, several concepts emerged on the subject, organized into two significant subcategories: physical and sexual violence.

In the subcategory physical violence, the participants expressed their knowledge about the subject, as mentioned in the following reports:

For me, violence against children has many aspects, well, there are many mothers who beat them to the point of leaving the child marked [...]. (M28)

One of the interviewees highlighted the physical violence perpetrated by the parents, as demonstrated in the following speech:
Oh, I think so, that there are parents who are very aggressive with their children, you know? They end up beating them, because then, in this case, I think violence is not just hitting, you know? The treatment, yelling, not being near, not caring, I think violence is part of all this, it's not just beating, you know? [...]. (M25)

Many parents use physical violence as a method to discipline children. However, they often exaggerate in their punishments, which can cause risks to the child's physical and mental health.

One of the mothers in the study clearly perceived the context of the difference between aggression and discipline, which is present in her speech:

There's a huge difference between assaulting and disciplining a child. [...] I am from the span of time. There is a difference in correcting, assaulting and spanking your child. [...]. (M3)

Mothers reflect in their lines that physical aggression is not the best way to educate their children, as evidenced in the following report:

[...] with my first child I did not have patience, I really beat him. But not nowadays, I understand today that beating is not appropriate [...]. (M28)

Physical violence is a complex phenomenon that constitutes a challenge and it can change the family relationship. Often, these acts of violence are silenced by those responsible themselves and used as a way of educating. Children that suffer from aggression may exhibit aggressive behaviors, as well as becoming sad and often experiencing learning difficulties.

Regarding the subcategory of sexual violence, there is a great concern among the interviewees regarding this type of violence, especially in relation to the fear of leaving children alone or with people they do not trust. The interesting thing about the speeches is that the mother linked in her testimonies this type of violence perpetrated by people close to the family. The following discourses are revealing in this sense:

Well, the violence against children is for me, I don't know, rape, it's like that, beating, when the uncle wants to abuse the child, uncle, father or brother, right? [...]. (M26)

[...] because sometimes we go to work and do not have anyone to stay with the child, and the child ends up being lonely and often neighbors or distant people observe the child and want to fool around with the child [...]. (M27)

The mothers speak of the likelihood of fathers committing this type of violence, as mentioned in the following report:

[...] I have a girl and sometimes I do not leave her at her father's house because I do not trust him, as we often see the father in this, that's it [...]. (M24)

In one of the mothers' statements it is possible to observe the authority of the aggressor regarding the life of the child who is a victim of sexual violence, when the mother expressed that 
[...] "If you tell your mother, I'll kill you," things like that [...]. (M26)

The abovementioned statement shows that the mother is aware of this type of violence when the aggressor threatens the child. However, the child is afraid of being punished and does not reveal this type of abuse, being fearful, unprotected, which also results in psychological violence.

\section{Threats of violence}

In the category of threats of violence, the interviewed participants gave rise to two important subcategories, being the street space and the family.

Mothers, when questioned about the measures of care they provided to protect their children from various kinds of violence, rather than pointing them out, they felt the need to point out the most significant sources of violence.

In the street space category, it was possible to perceive a certain apprehension and fear in relation to the street among the majority of the mothers $(63 \%)$. Through their reports, there is a great concern in not letting the children play in the streets:

[...] She asks to go to the street, then I say: "play here at home, dear!" (M1)

[...] By not letting them going to the street, I'm always looking after them. Because there is a lot of people who harm children. (M1)

For these mothers the street is a place that generates a sense of insecurity, "danger," and not a space to play and socialize, as they considered it a space of vulnerability concerning several forms of violence.

In the subcategory family, the participants' concern with the people of their own social life was also significant, stressing it as a threatening scenario for the child. A significant part of the mothers made clear in their speeches about their care not to leave children with people they did not trust:

Look, as I tell you, sometimes violence is inside the house and we do not even know. When I worked I did not leave my child with anyone. I don't trust anyone to leave the child in their care. No neighbor, uncle, cousin or anybody. The only person to this day is my mother. (M2)

Other people are presented by mothers as unreliable people. On the other hand, this mother pointed out the figure of the grandmother as a trustworthy person to care for her daughter, as in the following speech:

[...] Look! She only stays with my mother. I do not trust other people to leave her with someone else. (M23)

Often, the family space is a stage for several types of violence. In the mothers' speech, the violence that is closest to the child occurred when they placed the people present in their lives into this care:
[...] Because the violence is inside the house, what we see most is the uncle, the father, cousin abusing the child, and the danger is inside the house. (M3)

The family is an institution that, when approaching the context of violence against children, can be both the author and the greatest ally in the promotion and prevention of violence. The mothers in the study were able to have this perception; however, they regarded the family more as a risk than as a promoter of care:

[...] That's why I do not work, I stay at home, because of this, I do not trust anyone or even leave the child with my family, ok? Because we see so many situations like this, it is the uncle, even family, even inside our house, abusing children. (M21)

\section{Protective measures}

In the mothers' speech, when questioned about the methods they used to protect their children from several forms of violence, dialogue emerged in most speeches as a protective medium.

This subcategory was expressed in their responses, in which they verbalized that they seek to protect their children through dialogue printed in terms such as "orientations and conversations," which were the marker of the subcategory:

And so, talking to them too, I talk a lot with them, they are already grown up, I always talk like this: mommy, if someone calls you, do not go, do not leave this place, like that, guiding them, thus trying to protect them [...]. (M27)

However, it was not possible to observe how the experiences between the members of the several mothers of the study are sustained, as this factor is beyond the scope of this research. However, the mothers printed in their speeches that they used the dialogue as a resource to protect their children against violence:

[...] Guidance, I talk to him a lot. The key to everything is talking. I show the reality [...]. (M3)

Thus, analyzing the mothers' speech, communication is seen as a facilitating mechanism to guide the child so that he or she is able to distinguish early on what is right and wrong. Therefore, communication is so important to the development of bonds between mother and child. This relation needs to be established from the gestational course to the coexistence with the child. The affective relationships within the family, when dialogue, affection and respect prevail, direct a good behavior in the future life of the child, thus contributing to the non-reproduction of violence.

\section{DISCUSSION}

In this study, it was verified that mothers have a broad perspective on the phenomenon of violence, typifying their various natures. However, violence was markedly labeled as the physical and sexual violence against the child, since they were widely verbalized in their speeches. 
Studies point out that sexual violence is one of the most serious forms that affects children, while physical violence, through corporal punishment and repeated by many generations $^{(10)}$, is often understood as a way to discipline children, which can cause serious repercussions for their health ${ }^{(11)}$. The Information System of Notification of Injury (SINAN), in the year of 2012, indicates that the highest rate of violence was physical, with a total of 21,279 children and adolescents who suffered from it, in the range of 15 to 19 years of age. Secondly, sexual violence is highlighted, with 10,425 affected children and adolescents in the age group 5 to 14 years old ${ }^{(12)}$.

It should be emphasized that all forms of violence against children can result in psychological, cognitive and social problems, which can aggravate their health throughout their lives ${ }^{(13)}$. Violence generally occurs in the family sphere, which should be a source of protection and security. However, children are denied their rights and freedoms, and social issues are the reasons for the occurrence of violence in the family environment ${ }^{(11)}$.

Studies indicate that the practice of sexual violence against children and adolescents may be associated with the conflict of the aggressor in past childhood experiences of sexual abuse by people from their own family life, resulting in the person becoming an aggressor. Thus, the possibility of a child victimized in childhood becoming an aggressor in adulthood makes domestic violence a phenomenon of wide reach, which can involve several generations in its reproduction ${ }^{(14-15)}$.

Regarding the threats of violence, for the mothers of the present study, in the past the street was a place of joy, games, meetings, being a very important territorial landmark to stimulate child development. Today, for the vast majority of participants, the street is a propitiating stage for different types of violence.

Authors ${ }^{(16)}$ emphasize that the street space becomes a "scene" for conversations, meetings between friends, neighbors, games and children's games, passage, parties, among other events. However, the results of this research point a contradiction to this essence.

Historically in society, the family institution was considered the natural environment and the instrument of promotion, protection and guarantee of social rights for all its members. However, in our study, at no point, the mothers' speech, in its interpretative aspect as to what was discussed about violence, makes any allusion connecting family and protection. However, it prominently highlights the family as a threat and risk in which violence against children can occur. Article 4 of the Brazilian Statute of the Child and Adolescent, in order to ensure this protection $(\mathrm{ECA})^{(17)}$, determines:

It is the duty of the family, the community, society in general and the public power to ensure, with absolute priority, the realization of rights relating to life, health, food, education, sport, leisure, professionalization, culture, dignity, respect, freedom, and family and community coexistence.

The study's findings show that these rights are not yet being respected. However, for the mothers of this study, grandmothers not only actively participate in the education of their grandchildren, but also constitute the figure of greater trustworthiness and protection to care for their children.
Regarding protective measures, dialogue was strongly cited by most mothers as an important protective measure. For the mothers participating in the study, it is possible to protect their children against several types of violence through dialogue.

The culture of peace does not advocate the absence of conflict, but it strongly emphasizes the valorization of dialogue, negotiation and mediation between groups as a strategy for coexistence and conflict resolution ${ }^{(6)}$.

It is also worth noting that the concern about violence is linked to the promotion of a culture of peace as a way of countering the culture of violence. However, as in the literature, the mothers of our study recognize the use of dialogue as a way of approaching the prevention of violence against their children.

The authors understand that the culture of peace must be built mainly within the family: "It is in the family that the child will obtain their emotional and educational basis that will accompany them in all phases of their life. It will be with the basis of solid family relationships that children will constitute their first beliefs about themselves and others"(18).

\section{Study limitations}

Little or almost nothing has been observed to implement care lines in the healthcare network with actions to prevent violence and to promote a culture of peace with families. In this sense, incipient actions aimed at the community and without the participation of several groups, mainly of the mothers, weaken the confrontation to the phenomenon. Another limiting factor of this study is the scarcity of scientific productions on the subject in the Brazilian field of nursing, but mainly in the Northern Region of the country, more specifically in the state of Pará.

Contributions to the fields of nursing, health or public policy Violence in many ways affects health, the full development and citizenship of people. It may be the result of policy decisions. Thus, it is undeniable that health professionals, especially nurses, are involved in the process of defending the rights of the child's citizenship, considering the closeness of these professionals to the community. This closeness can be a guiding factor for ethical principles, especially as nursing is a profession committed to the health of the human being and the community. Thus, it is fundametal to develop strategies of actions and care that guarantee the children the fullness of their healthy development, far from any possibility of violence that entails in damages to their health, which lead to psychological suffering that can generate immediate damages such as anxiety, anger, guilt, shame, phobia, depressions, psychosomatic complaints and social isolation. There are also late injuries, such as psychiatric disorders, suicidal ideation, intense anxiety, fear and hostility, which also require family involvement to be avoided. There is also a need to build an institutional network that involves all those situations and institutions that participate in political movements in the fight against violence.

\section{FINAL REMARKS}

Mothers attributed different meanings to the phenomenon of violence; however, they emphasized physical and sexual violence as 
the most overwhelming ones, because they are the ones that surround most childhood. Violence is everywhere, but for the mothers of the study, the street that once played a role as a place of joy, play, is now a conducive stage for the various types of violence.

Historically, the family institution has always been considered the instrument of promotion, protection and guarantee of social rights for all its members. However, in this study, at no time in the mothers' speech, in its interpretative aspect regarding what was discussed about violence, the mothers made any allusion connecting family and protection, although they have markedly highlighted the family as a threat and a risk for the security of children.
The measures used by mothers to promote protection against other forms of violence are established in their family relationships through dialogue, conversations and guidance given to their children. Dialogue strengthens healthy affective bonds in this phase of the human development, it reinforces, throughout life, attitudes of self-confidence, cooperation, solidarity and responsibility, elements that propel personal and collective growth.

Thus, the participation of nurses in a firm performance, especially in the development of educational activities that promote the culture of peace between the families belonging to their service, becomes extremely relevant.

\section{REFERENCES}

1. Almeida MGB. A violência na sociedade contemporânea. Porto Alegre; EDIPUCRS; 2010.

2. Krug EG(Ed.). World report on violence and health. Geneva, World Health Organization, 2002.

3. Galheigo SM. Apontamentos para se pensar ações de prevenção à violência pelo setor saúde. Saúde Soc[Internet]. 2008[cited 2016 Sep 12];17(3):181-9. Available from: http://www.scielo.br/pdf/sausoc/v17n3/18.pdf

4. Carvalho QCM, Cardoso MVLML, Silva MJ, Braga VAB, Galvão MTG. Violência contra criança e adolescente: reflexão sobre políticas públicas. Rev Rene[Internet]. 2008[cited 2016 Sep 12];9(2):157-64. Available from: http://www.periodicos.ufc.br/rene/ article/view/5056/3711

5. Ramos MLCO, Silva AL. Estudos sobre a violência doméstica contra a criança em unidades básicas de saúde do município de São Paulo, Brasil. Saúde Soc[Internet]. 2011[cited 2016 Sep 05];20(1):136-46. Available from: http://www.scielo.br/pdf/sausoc/ v20n1/16.pdf

6. Ferreira FR. A prevenção da violência e promoção da cultura de paz: o papel da saúde pública [dissertação]. São Paulo: VGV; 2012 [cited 2016 Sep 05]. Available from: http://bibliotecadigital.fgv.br/dspace/bitstream/handle/10438/10071/Trabalho\% 20 Individual $\%$ 20Fernanda $\% 20$ Ran $\%$ C3\%B1a\%20Ferreira.pdf?sequence $=1$

7. Brasil. Conselho Nacional de Saúde. Resolução ${ }^{\circ}$ 466, de 12 de dezembro de 2012, aprova as diretrizes e normas regulamentadoras de pesquisas envolvendo seres humanos[Internet]. Diário Oficial da União. 13 junho 2013. 2013[cited 2016 Oct 21]. Available from: http://conselho.saude.gov.br/resoluções/2012/reso466.pdf

8. Brasil. Instituto Brasileiro de Geografia e Estatística (IBGE). Censo Demográfico 2010[Internet]. 2010 [cited 2016 Oct 21]. Available from: http://www.censo2010.ibge.gov.br/sinopse/index.php? uf $=31 \&$ dados $=0$

9. Bardin L. análise de conteúdo. Lisboa: edições 70; 2011.

10. Rocha PCX, Moraes CL. Violência familiar contra a criança e perspectivas de intervenção do Programa Saúde da Família: a experiência do PMF/Niterói (RJ, Brasil). Ciênc Saúde Colet [Internet]. 2011[cited 2016 Sep 12];16(7):3285-96. Available from: http://www.scielo.br/pdf/csc/v16n7/28.pdf

11. Zanelatto PF, Medeiros M, Silva SW, Bouttelet MD. Violência contra crianças e adolescentes: significados e atitudes por equipes da estratégia saúde da família. Ciênc Enferm[Internet]. 2012 [cited 2016 Sep 12];18(2):41-9. Available from: http://www.scielo. $\mathrm{cl} /$ pdf/cienf/v18n2/art_05.pdf

12. Waiselfisz JJ. Mapa da violência 2012: Criança e adolescentes do Brasil. Rio de Janeiro: 2012.

13. Brasil. Ministério da Saúde. Secretaria de Atenção à Saúde. Departamento de Ações Programáticas Estratégicas. Linha de cuidado para a atenção integral à saúde de crianças, adolescentes e suas famílias em situação de violência: orientação para gestores e profissionais de saúde. Brasília: Ministério da Saúde; 2010.

14. Pinto Junior AA, Lopes DC, Pinheiro VS, Ortiz MM, Oliveira SL. Perfil da violência sexual doméstica contra crianças e adolescentes no município de Dourados/MS. Rev Psicol Saúde[Internet]. 2012 jan-jun[cited 2016 Sep 22];4(1):59-68. Available from: http:// www.gpec.ucdb.br/pssa/index.php/pssa/article/viewFile/125/221

15. Azevedo MA, Guerra VMA. Violência doméstica na infância e na adolescência: uma nova cultura de prevenção. São Paulo: Plêiade/FAPESP; 2011.

16. Oliveira PT, Lopes MF. Brincadeira no espaço da rua e a demarcação dos gêneros na infância. Rev Latinoam Cienc Soc Niñez Juv [Internet]. 2009[cited 2016 Sep 12];7(2):861-85. Available from: http://www.scielo.org.co/pdf/rlcs/v7n2/v7n2a12.pdf

17. Estatuto da Criança e do Adolescente: lei n 8.069, de 13 de julho de 1990 e legislação correlata. 11.ed. Brasília: edições Câmara; 2014.

18. Morais LAW. Família e filhos[Internet]. 2016 [cited 2016 Sep 25]. Available from: http://www.psicologiasdobrasil.com.br/ familia-e-filhos-vinculos/ 